\title{
Pengaruh Kinerja Guru dalam Pelaksanaan Pembelajaran terhadap Prestasi Belajar Siswa pada Mata Pelajaran Alquran-Hadis
}

\author{
Mohamad Sodik \\ Institut Agama Islam Darussalam (IAID) Ciamis, Jawa Barat. \\ Email:msodik1995@gmail.com \\ Yosef Farhan Dafik Sahal \\ Fakultas Tarbiyah, Institut Agama Islam Darussalam (IAID) Ciamis, Jawa Barat. \\ Email: yosep.farhands@gmail.com \\ N. Hani Herlina \\ Program Pascasarjana, Institut Agama Islam Darussalam (IAID) Ciamis, Jawa Barat. \\ Email: nhani_herlina@yahoo.co.id
}

Received: November 1, 2018 | Accepted: March 8, 2019

\begin{abstract}
This research is motivated by the discovery of problems related to the performance of teachers in the implementation of learning the Qur'an-Hadith. After conducting an interview with the school principal, it turns out that students experience and feel how a teacher is carrying out learning, Class V in MIN 10 Ciamis student grades are above the KKM as a whole with an average of 84.59 . Therefore research is needed regarding the effect of teacher performance in the implementation of learning. The purpose of this study is: to determine the performance of teachers in the implementation of learning the subjects of Qur'an-Hadith class V at MIN 10 Ciamis, to determine student learning achievements in subjects Qur'an-Hadith class V at MIN 10 Camis, to find out the effect of teacher performance in the implementation of learning on student achievement in the subjects of the Koran class V in Hadith 10 Ciamis. To get the data of this study, the authors used a descriptive correlational method with a quantitative approach and used data collection techniques with observation, distributing questionnaires to 39 respondents, interviews and documentation studies. The results of this study indicate that the Significance value of $0.959>0.05$, which means that there is an influence of teacher performance in the implementation of learning on student achievement in the subjects of Qur'an-Hadith class V at MIN 10 Ciamis.
\end{abstract}

\begin{abstract}
Abstrak
Penelitian ini dilatarbelakangi oleh ditemukannya permasalahan yang berkaitan dengan kinerja guru dalam pelaksanaan pembelajaran Alquran-Hadis. Setelah melakukan wawancara dengan kepala sekolah, ternyata siswalah yang mengalami dan merasakan bagaimana seorang guru
\end{abstract}


melaksanakan pembelajaran. Nilai siswa Kelas V di MIN 10 Ciamis sudah berada diatas KKM secara keseluruhan dengan rata-rata mencapai 84,59. Oleh karena itu diperlukan adanya penelitian mengenai pengaruh kinerja guru dalam pelaksanaan pembelajaran. Tujuan penelitian ini adalah untuk mengetahui kinerja guru dalam pelaksanaan pembelajaran mata pelajaran Alquran-Hadis kelas V di MIN 10 Ciamis, prestasi belajar siswa pada mata pelajaran Alquran-Hadis kelas V di MIN 10 Camis, serta pengaruh kinerja guru dalam pelaksanaan pembelajaran terhadap prestasi belajar siswa pada mata pelajaran Alquran Hadis kelas V di MIN 10 Ciamis. Untuk mendapatkan data penelitian ini, penulis menggunakan metode deskriptif-korelasional dengan pendekatan kuantitatif serta menggunakan teknik pengumpulan data dengan observasi, penyebaran angket ke 39 responden, interview dan studi dokumentasi. Hasil penelitian ini menunjukkan bahwa nilai Signifikansi 0,959>0,05 yang berarti ada pengaruh kinerja guru dalam pelaksanaan pembelajaran terhadap prestasi belajar siswa pada mata pelajaran Alquran Hadis kelas V di MIN 10 Ciamis.

\section{Keywords}

Islamic education, teacher performance, learning achievement

\section{Pendahuluan}

Masalah pendidikan merupakan persoalan yang tidak pernah sepi dibicarakan dan dikritik para pakar. Kritik yang dibahas dalam dunia pendidikan umumnya mengenai peserta didik, proses mutu, kurikulum, serta guru yang mendampingi jalannya proses pembelajaran. Pendidikan yang dilaksanakan di sekolah belum sepenuhnya memenuhi harapan masyarakat. Fenomena ini ditandai dari rendahnya mutu lulusan, penyelesaian pendidikan yang tidak tuntas, belum pernah ada kurikulum yang bertahan lama diakibatkan dari kebiasaan manusia yang selalu berubah dari kebiasaan lama menjadi kebiasaan baru, seterusnya akan silih berganti sesuai dengan perkembangan zaman.

Kedudukan guru dalam kegiatan proses pembelajaran juga sangat strategis dalam menjelaskan suatu pembelajaran. Karena guru yang akan menentukan kedalaman dan keluasan materi pelajaran. Guru juga yang memilah dan memilih bahan pelajaran yang akan disajikan kepada peserta didik. Setiap siswa memiliki kemampuan yang berbeda-beda, maka dari itu hasilnya pun akan berbeda. Namun demikian, dari arahan seorang guru dan kesungguhan siswa dalam belajar, maka peserta didik akan menemukan titik kesamaan kemampuan. Guru yang memiliki kinerja yang baik akan mempengaruhi terhadap siswanya, sehingga guru harus selalu melihat kekurangan dirinya agar dapat memperbaiki kekurangan tersebut.

Pembelajaran merupakan suatu sistem yang terdiri dari berbagai komponen yang saling berhubungan satu dengan yang lainnya. Komponen 
tersebut meliputi: tujuan, materi, metode, strategi dan pendekatan apa yang akan digunakan dalam kegiatan pembelajaran. Pembelajaran pada hakikatnya merupakan proses interaksi antara guru dengan siswa, baik interaksi secara langsung, seperti kegiatan tatap muka, maupun secara tidak langsung, seperti dengan menggunakan berbagai media pembelajaran.

Sejalan dengan pendapat di atas, menurut Rusman, "pembelajaran adalah suatu usaha untuk membuat peserta didik belajar atau suatu kegiatan untuk pembelajaran peserta didik" (Rusman, 2015, p. 21). Dengan kata lain, pembelajaran merupakan upaya menciptakan kondisi agar terjadi kegiatan belajar. Pembelajaran itu menunjukkan pada usaha siswa mempelajari bahan pelajaran sebagai akibat perlakuan guru.

Pengetahuan, pemahaman dan pelaksanaan nilai-nilai agama pada mata pelajaran Alquran-Hadis membuktikan terjadinya pembelajaran yaitu masuk pada aspek kognitif, afektif dan psikomotorik. Pada prosesnya, seorang guru sangat berperan dalam pencapaian prestasi siswa di MIN 10 Ciamis. Hal tersebut dibuktikan dengan adanya peningkatan nilai ulangan semester dan mencapai Kriteria Kentuntasan Minimal (KKM) setelah guru melaksanakan pembelajaran mata pelajaran Alquran-Hadis dengan metode dan model pembelajaran yang inovatif. Namun di sisi lain, setelah penulis melakukan wawancara dengan kepala sekolah, ternyata kepala sekolah belum bisa memastikan kinerja guru dalam pelaksanaan pembelajaran, apakah sudah mencapai tingkat yang diharapkan atau belum. Karena dalam pelaksanaannya, hanya para siswa yang dapat merasakannya selama pembelajaran berlangsung. Siswa mungkin sudah terbiasa didapat dari pembelajaran di keluarga, lingkungan masyarakat seperti sekolah diniyyah dan pengajian rutin setelah solat magrib. Hipotesis dalam penelitian ini yaitu terdapat pengaruh kinerja guru dalam pelaksanaan pembelajaran terhadap prestasi belajar siswa pada mata pelajaran Alquran Hadis siswa kelas V MIN 10 Ciamis.

\section{Kerangka Teori}

Manusia adalah unsur utama dalam pencapaian tujuan organisasi. Pemikiran ini berimplikasi kepada bagaimana personil dalam organisasi bekerja untuk mencapai tujuan tersebut. Bagaimana seorang personil bekerja dengan baik dalam suatu konsep yang sudah ada. Kinerja merupakan suatu kegiatan yang dilakukan untuk melaksanakan, menyelesaikan tugas dan tanggung jawab sesuai dengan harapan dan tujuan yang telah ditetapkan. Secara bahasa, istilah kinerja berasal dari kata performance. Kata performance memberikan tiga arti, yaitu: (1) Prestasi, seperti dalam konteks atau kalimat high performance car, atau mobil yang sangat cepat; (2) Pertunjukan, seperti dalam konteks atau kalimat 
folk dance performance atau pertunjukan tari-tarian rakyat; (3) Pelaksanaan tugas, seperti dalam konteks atau kalimat in performing his/her duties (Supardi, 2013, p. 45).

Hasil pemahaman bahwa kinerja merupakan pelaksanaan pekerjaan sesuai dengan persyaratan pekerjaan, maka kinerja merupakan pelaksanaan kerja seorang guru sesuai dengan tugas-tugasnya yang diembannya. Tugastugas guru pada prinsipnya terkandung dalam kompetensi yang seharusnya dimiliki oleh seorang guru.

Terdapat beberapa model kinerja (performance) guru dalam melaksanakan proses belajar mengajar, di antaranya adalah model Rob Norris, Model Oregan dan Model Stanford. Tiga macam model ini dikenal dengan Stanford Teacer of Appraisal Competence (STAC). Model Rob Norris memaparkan bahwa di antara komponen kompetensi mengajar yang harus dimiliki oleh seorang guru, adalah: (a) Kualitas-kualitas personal dan profesional; (b) Persiapan mengajar; (c) Perumusan tujuan pengajaran; (d) Penampilan guru dalam mengajar di kelas; (e) Penampilan siswa dalam belajar; (f) Evaluasi. (Barizi, 2009, p. 151).

Model Oregan mengelompokan kompetensi/kemampuan mengajar kedalam lima kelompok, yaitu: (a) Perencanaan dan persiapan mengajar; (b) Kemampuan guru dalam mengajar dan kemampuan siswa dalam belajar; (c) Kemampuan mengumpulkan dan menggunakan informasi hasil belajar; (d) Kemampuan hubungan interpersonal yang meliputi hubungan dengan siswa, supervisor, dan guru sejawat; (e) Kemampuan hubungan dengan tanggungjawab profesional.

Penilaian kinerja dapat diartikan sebagai hasil dari sebuah proses yang berlangsung pada kegiatan tertentu. Proses penilaian kinerja adalah kegiatan yang bertujuan menilai seseorang atau dalam organisasi (kelompok) yang bermanfaat bagi orang lain.

Dalam pandangan Michel, sebagaimana dikutip Veithzal, aspek yang dilihat dalam menilai kinerja individu (termasuk guru) adalah qualty of work, proptness, initiatif, capability and communication, yaitu suatu penilaian yang dipandang dari penguasaan keilmuan, keterampilan, tingkah laku, kemampuan membina hubungan, kualitas kerja, inisiatif, kapasitas diri, serta kemampuan dalam berkomunikasi. Sementara aspek-aspek yang dapat dinilai dari kinerja seorang guru dalam suatu organisasi dikelompokan menjadi tiga, yaitu kemampuan teknik, kemampuan konseptual dan kemampuan hubungan interpersonal (Veithzal, 2004, p. 324).

Mengacu kepada uraian Supardi, kemampuan teknik adalah kemampuan menggunakan pengetahuan, metode, teknik, dan peralatan yang dipergunakan untuk melaksanakan tugas serta pengalaman dan pelatihan yang diperoleh. 
Sementara konseptual yaitu kemampuan untuk memahami kompleksitas organisasi dan penyesuaian bidang gerak dari unit-unit operasional. Adapun kemampuan hubungan interpersonal yaitu antara lain membawa guru melakukan negosiasi (Supardi, 2013, p. 71).

Agar penilaian kinerja guru mudah dilaksanakan serta membawa manfaat diperlukan pedoman dalam penilaian kinerja. Menurut Manusung dalam Supardi, pedoman penilaian terhadap kinerja guru mencakup: (1) Kemampuan dalam memahami materi bidang studi yang menjadi tanggung jawabnya (subject mastery and content knowledge); (2) Keterampilan metodologi yaitu merupakan keterampilan cara penyampaian bahan pelajaran dengan metode pembelajaran yang bervariasi (metodological skills atau technicall skils); (3) Kemampuan berinteraksi dengan peserta didik sehingga tercipta suasana pembelajaran yang kondusif yang bisa memperlancar pembelajaran; (4) Sikap profesional (professional standard-professional attitude) yang turut menentukan keberhasilan seorang guru di dalam melaksanakan kegiatan pembelajaran sesuai dengan panggilan sebagai seorang guru (Supardi, 2013, p. 72).

Banyak faktor yang mempengaruhi kinerja organisasi maupun individu. Adapun faktor-faktor yang mempengaruhi prestasi kerja atau kinerja seseorang antara lain adalah lingkungan, perilaku manajemen, desain jabatan, penilaian kinerja, umpan balik dan administrasi pengupahan. Sedangkan komplemen menyatakan bahwa kinerja organisasi ditentukan oleh 4 faktor, yaitu lingkungan, karakteristik individu, karakteristik organisasi dan karakteristik pekerjaan. Dengan demikian, dapat diartikan bahwa kinerja pengawas sangat dipengaruhi oleh karakteristik individu yang terdiri atas pengetahuan, keterampilan, kemampuan, motivasi, kepercayaan, nilai-nilai, serta sikap. Karakteristik individu sangat dipengaruhi oleh karakteristik organisasi dan karakteristik pekerjaan.

Berkenaan dengan kepentingan penilaian terhadap kinerja guru, Georgia Departemen of Education telah mengembangkan Teacher Performance Assessment Instrument yang kemudian dimodifikasi oleh Depdiknas menjadi Alat Penilaian Kemampuan Guru (APKG). Alat penilaian kemampuan guru, meliputi: (1) Rencana pembelajaran (teaching plans and materials) atau disebut dengann RPP (Rencana Pelaksanaan Pembelajaran); (2) Prosedur pembelajaran (classroom procedure); (3) Hubungan antar pribadi (interpersonal skill).

Sementara itu, indikator kinerja guru dilakukan terhadap tiga kegiatan pembelajaran di kelas mencakup perencanaan program kegiatan pembelajaran dan evaluasi/penilaian pembelajaran. Kegiatan pembelajaran di kelas adalah inti penyelenggaraan pendidikan yang ditandai oleh adanya kegiatan pengelolaan kelas, penggunaan media dan sumber belajar dan penggunaan metode serta strategi pembejaran. Semua tugas tersebut merupakan tugas dan tanggung 
jawab guru yang secara optimal dalam pelaksanaanya menuntut kemampuan guru. Sementara penilaian hasil belajar adalah kegiatan atau cara yang ditujukan untuk mengetahui tercapai atau tidaknya tujuan pembelajaran dan juga proses pembelajaran yang telah dilakukan. Pada tahap ini seorang guru dituntut memiliki kemampuan dalam menentukan pendekatan dan cara-cara evaluasi, penyusunan alat-alat evaluasi, pengolahan, dan penggunaan hasil evaluasi.

Pendekatan atau cara yang dapat digunakan untuk melakukan evaluasi/penilaian hasil belajar adalah melalui Penilaian Acuan Norma (PAN) dan Penilaian Acuan Patokan (PAP). PAN adalah cara penilaian yang tidak selalu tergantung pada jumlah soal yang diberikan atau penilaian dimasudkan untuk mengetahui kedudukan hasil belajar yang dicapai berdasarkan norma kelas. Siswa yang paling besar skor yang didapat di kelasnya adalah siswa yang memiliki kedudukan tertinggi di kelasnya. Sedangkan PAP adalah cara penilaian, yakni ketika nilai yang diperoleh siswa tergantung pada seberapa jauh tujuan yang tercermin dalam soal-soal tes yang dapat dikuasai siswa. Nilai tertinggi adalah nilai sebenarnya berdasar-kan jumlah soal tes yang dijawab dengan benar oleh siswa. Dalam PAP ada passing grade atau batas lulus, apakah siswa dapat dikatakan lulus atau tidak berdasarkan batas lulus yang telah ditetapkan.

Dalam melaksanakan pembelajaran di dalam kelas, menurut Majid, guru harus memiliki kemampuan membuka pelajaran, menyajikan materi, menggunakan metode/media, menggunakan alat peraga, menggunakan bahasa yang komunikatif, memotivasi siswa, mengorganisasi kegiatan, berinteraksi dengan siswa secara komunikatif, menyimpulkan pembelajaran, memberikan umpan balik, melaksanakan penilaian, serta menggunakan waktu secara optimal (Majid, 2012, p. 7).

\section{Metode Penelitian}

Jenis dan metode yang digunakan dalam penelitian ini disesuaikan dengan permasalahannya, yakni penelitian kuantitatif dengan menggunakan metode deskriptif-korelasional. Metode ini digunakan untuk menganalisa gambaran yang terjadi pada saat dilakukannya penelitian, yakni kajian terhadap kinerja guru dalam pelaksanaan pembelajaran serta pengaruhnya terhadap prestasi belajar siswa kelas V MIN 10 Ciamis. Metode deskriptif adalah suatu metode dalam meneliti status sekelompok manusia, suatu objek, kondisi, sistem pemikiran, ataupun peristiwa pada masa sekarang (Nazir, 1988, p. 63).

Kata korelasi diambil dari bahasa inggris yaitu correlation, artinya saling hubungan atau hubungan timbal-balik. Dalam ilmu statistika, istilah korelasi 
diberi pengertian sebagai hubungan antara dua variabel atau lebih. Hubungan antara dua variabel dikenal dengan istilah bivariate correlation, sedangkan hubungan antar lebih dari dua variabel disebut multivariate correlation. Contoh bivariate correlation: hubungan antara motivasi kerja dan disiplin kerja dengan kinerja.

Tujuan dilakukannya analisis korelasi antara lain, (a) untuk mencari bukti terdapat tidaknya hubungan (korelasi) antar variabel, (b) bila sudah ada hubungannya, untuk melihat besar kecilnya hubungan antar variabel, dan (c) untuk memperoleh kejelasan dan kepastian apakah hubungan tersebut berarti (meyakinkan/signifikan) atau tidak berarti (tidak meyakinkan) (Somantri \& Muhidin, 2006, p. 206).

Apabila kita punya dua buah variabel $\mathrm{X}$ dan $\mathrm{Y}$ yang kedua-duanya punya tingkat pengukuran ordinal, maka parameter yang bisa menyatakan hubungan kedua variabel itu adalah koefisien korelasi Spearman (Spearman's Coefficient of (Rank) Correlation), serta koefisien korelasi Kendall (Kendall's Coefficient of (Rank) Correlation). Oleh karena penelitian tentang kinerja guru dalam pelaksanaan pembelajaran terhadap prestasi belajar siswa kelas $\mathrm{V}$ pada mata pelajaran Alquran-Hadis, maka metode yang digunakannya adalah metode deskriptif-korelasional.

Adapun teknik pengumpulan data yang digunakan dalam penelitian ini adalah menggunakan angket. Menurut Arikunto, angket adalah sejumlah pertanyaan yang digunakan untuk memperoleh informasi dalam arti laporan tentang dirinya, atau hal lain yang ia ketahui (Arikunto, 2000, hal. 140). Sejalan dengan pendapat Ridwan, angket adalah cara pegumpulan data dengan mempergunakan pertanyaan-pertanyaan tertulis untuk memperoleh informasi dan responden sesuai dengan permintaan pengguna (Ridwan, 2007, p. 71). Bentuk angket yang digunakan dalam penelitian ini adalah angket tertutup dengan memberi tanda silang (X). Selanjutnya angket diberikan kepada siswa dengan mengacu kepada indikator-indikator kinerja guru dalam pelaksanaan pembelajaran.

Selain angket, pengumpulan data juga dengan menggunakan studi dokumentasi, yaitu kegiatan tindakan yang dilakukan dengan mengabadikan gambar suatu keadaan yang berhubungan dengan tempat, objek, tindakan, aktivitas, kejadian dalam proses pengisian angket dan data-data lain yang terkait dengan penelitian yang ada di MIN 10 Ciamis. Sugiyono menjelaskan bahwa dokumen merupakan catatan peristiwa yang sudah berlalu. Dokumen bisa berbentuk tulisan, gambar, atau karya-karya monumental dari seseorang (Sugiyono, 2009, p. 329). Studi dokumentasi merupakan suatu teknik pengumpulan data dengan cara mempelajari dokumen untuk mendapatkan data atau informasi yang berhubungan dengan masalah yang diteliti. Studi 
dokumentasi dalam penelitian ini adalah dengan meminta data-data dari pihak sekolah. Misalnya saja, mengenai tata tertib sekolah, jadwal kegiatan belajarmengajar dan lain-lainnya. Hal ini dilakukan agar informasi yang didapatkan benar-benar bersumber dari objek yang dijadikan sebagai tempat penelitian. Teknik dokumentasi dilakukan dalam bentuk memotret semua kejadian yang berlangsung selama peneliti melakukan kegiatan penelitian. Sedangkan untuk memperoleh data prestasi belajar siswa pada mata pelajaran Alquran-Hadis didapat dengan cara menghimpunnya dari buku daftar nilai Ujian Tengah Semester (UTS) di kelas V MIN 10 Ciamis.

Menurut Sulistyo, ada dua macam teknik analisis data dalam penelitian kuantitatif, yaitu, pertama, teknik statistik deskriptif yang digunakan pada penelitian yang bertujuan menggambarkan keadaan suatu gejala sosial apa adanya, tanpa melihat hubungan-hubungan yang ada. Kedua, teknik statistik inferensial yang digunakan pada penelitian yang bertujuan untuk melihat hubungan-hubungan antara gejala-gejala yang ada (Sulistyo, 2010, p. 14). Selaras dengan itu, Sukardi menjelaskan bahwa kegiatan yang dilakukan dalam analisis data adalah mendeskripsikan data dan melakukan uji statistika (Sukardi, 2007, p. 86).

Setelah proses pengumpulan, langkah selanjutnya adalah, pertama, mendeskripsikan data. Menurut Sukardi, pendeskripsian data dilakukan dengan cara sebagai berikut mengukur tendensi sentral yang meliputi mean, median, dan modus; mengukur variabilitas, yang meliputi standar deviasi, varian, quartil, desil dan persentil; serta mengukur perbandingan dan posisi skor dalam bentuk tabel distribusi frekuensi dan grafik (histogram) (Sukardi, 2007, pp. 86-87).

Kedua, melakukan uji statistika. Uji statistika dilakukan penulis setelah terlebih dahulu mengadakan pengujian persyaratan, yakni: (1) Uji normalitas. Menurut Priyatno, tujuan uji normalitas menurut adalah untuk mengetahui normal atau tidaknya distribusi suatu data (Priyatno, 2008, p. 28). Selain itu, menurut Sulistyo, uji normalitas juga dimaksudkan untuk memperlihatkan bahwa sampel diambil dari populasi yang berdistribusi normal (Sulistyo, 2010, p. 50). Uji normalitas ini dilakukan penulis dengan menggunakan uji Kolmogorov-Smirnov; (2) Uji linearitas. Menurut Priyatno, tujuan uji linearitas adalah untuk mengetahui apakah variabel $\mathrm{X}$ dan variabel $\mathrm{Y}$ memiliki hubungan yang linear atau tidak secara signifikan. Uji ini pada umumnya digunakan sebagai prasyarat dalam analisis korelasi atau regresi linear (Priyatno, 2008, p. 36).

Khusus dalam melakukan pengujian hipotesis, penulis melakukannya dengan, pertama, uji regresi. Hal ini dilakukan untuk menentukan persamaan regresi dan koefisien regresi. Sebagaimana dijelaskan oleh Priyatno, uji regresi 
adalah untuk mengetahui arah hubungan antara variabel $X$ dengan variabel $Y$ (apakah positif atau negatif), serta untuk memprediksi nilai dari variabel Y jika nilai variabel $X$ mengalami fluktuasi (Priyatno, 2008, p. 66). Sementara penentuan nilai koefisien korelasi, sebagaimana dipaparkan Priyatno, dilakukan untuk menentukan nilai koefisien korelasi, sehingga dapat diketahui keeratan hubungan dan arah hubungan antara variabel $\mathrm{X}$ dan variabel $\mathrm{Y}$ (Priyatno, 2008, p. 53). Kedua, uji signifikansi koefisien korelasi. Menurut Priyatno, uji signifikansi koefisien korelasi dilakukan dengan tujuan untuk menguji dapat atau tidaknya hubungan yang terjadi berlaku untuk populasi (Priyatno, 2008, p. 56).

\section{Hasil Penelitian dan Pembahasan}

Berdasarkan hasil penelitian dan analisa data tentang pokok permasalahan dalam laporan skripsi yang telah dipaparkan pada bab-bab sebelumnya, yaitu mengenai pengaruh kinerja guru dalam pelaksanaan pembelajaran pada mata pelajaran Alquran-Hadis di MIN 10 Ciamis, maka dapat diambil beberapa kesimpulan, diantaranya: (1) Kinerja guru dalam pelaksanaan pembelajaran pada mata pelajaran Alquran-Hadis Kelas V di MIN 10 Ciamis mencapai ratarata 49,38. Sementara standar deviasi sebesar 3,85. Adapun interpretasi jawaban responden pada angket menunjukkan kualifikasi cukup. (2) Prestasi belajar siswa pada mata pelajaran Alquran-Hadis berdasarkan hasil penelitian diperoleh rata-rata sebesar 84,59 dengan standar deviasi 5,50. Hal ini menunjukkan kualifikasi sangat tinggi. (3) Hasil penelitian ini menunjukkan bahwa nilai signifikansi $0,959>0,05$ yang berarti ada pengaruh kinerja guru dalam pelaksanaan pembelajaran terhadap prestasi belajar siswa pada mata pelajaran Alquran-Hadis kelas V di MIN 10 Ciamis.

Untuk mengumpulkan dan mengetahui data tentang kinerja guru dalam pelaksanaan pembelajaran pada mata pelajaran Alquran-Hadis Kelas V di MIN 10 Ciamis (variabel X), penulis memberikan angket yang harus diisi oleh para siswa tersebut. Kelas yang di observasi yaitu kelas V yang berjumlah 39 (tiga puluh sembilan) siswa.

Dari perhitungan SPSS versi 20 tersebut di atas, diketahui bahwa ratarata (mean) untuk variabel kinerja guru dalam pelaksanaan pembelajaran kelas V MIN 10 Ciamis adalah 49,38 dengan skor terkecil (minimum) adalah 42 dan skor terbesar (maximum) adalah 56. Perbedaan antara nilai tertinggi dan terendah (Range) adalah 14, sedangkan untuk standar deviation adalah 3,85.

Dengan nilai rata-rata sebesar 49,38, maka dapat dikatakan bahwa kinerja guru dalam pelaksanaan pembelajaran pada mata pelajaran AlquranHadis di Kelas V MIN 10 Ciamis termasuk kategori cukup, karena jumlah 
rata-rata $($ mean $)=49,38: 15$ (jumlah butir angket $)=3,29$. Nilai 3,29 ini termasuk pada kategori cukup karena berada pada interval 2,6 - 3,5. Sedangkan dari hasil perhitungan variabel Y (motivasi shalat Dzuhur berjama'ah siswa kelas VII di SMPN 5 Rajadesa Kabupaten Ciamis) memiliki nilai tertinggi 73 dan nilai terendah 40 sehingga rentangnya (Range) 33 dan rata-rata (Mean) nilainya 60,91. Sedangkan standar deviasinya sebesar 8,133. Nilai rata-rata diubah ke dalam bentuk persentase dihitung dengan cara nilai rata-rata hitung dibagi nilai kemungkinan skor tebesar di kalikan 100, sehingga didapat $60,91: 73 \times 100 \%=83,43 \%$. Dengan rata-rata 83,43. Bila dikonversikan dengan kriteria keberhasilan, maka berada pada rentang nilai antara 80 - 100, dengan demikian dapat disimpulkan bahwa rata-rata variabel Y yaitu motivasi Shalat berjama'ah Siswa Kelas VII di SMPN 5 Rajadesa Kabupaten Ciamis berada dalam korelasi kuat.

Berdasarkan ketentuan, jika nilai Asymp.Sig lebih besar dari 0,05 maka variabel tersebut berasal dari populasi yang berdistribusi normal. Namun sebaliknya, jika nilai sig lebih kecil dari 0,05 maka variabel tersebut berasal dari populasi berdistribusi tidak normal. Maka sesuai dengan ketentuan diatas, dengan menggunakan uji Test of Normality, tampak bahwa nilai sig adalah 0,039 yang lebih kecil dari 0,05 . Dengan demikian dapat disimpulkan bahwa distribusi nilai kompetensi guru berdistribusi tidak normal.

Dwi Priyatno mengemukakan bahwa uji linealitas bertujuan untuk menguji apakah variabel mempunyai hubungan yang linear secara signifikan atau tidak (Priyatno, 2008, p. 36). Berdasarkan nilai signifikansi dari output di atas, diperoleh nilai signifikansi 0,405 lebih besar dari 0,05. Artinya, hubungan data variabel $\mathrm{X}$ dengan variabel $\mathrm{Y}$ tidak linier. Maka berdasarkan hasil dari perhitungan regresi sederhana, dapat diperoleh harga persamaan regresi sebagaimana dirangkum pada tabel di atas. Hal ini menggambarkan hubungan variabel $X$ dengan variabel $Y$ konstanta pada kolom $B=53,565$, dan variabel $X$ $=0,108$. Dengan demikian keputusan yang diambil terhadap hipotesa yang diajukan adalah menolak $\mathrm{H} 0$ dan menerima Hi. Maka hipotesa yang berbunyi, "semakin baik pembelajaran PAI kelas VII, maka akan semakin baik pula motivasi shalat Dzhuhur berjama'ah siswa kelas VII di SMPN 5 Rajadesa Kabupaten Ciamis.”

Sedangkan variabel Y (prestasi belajar siswa pada mata pelajaran AlquranHadis di Kelas V MIN 10 Ciamis), berdasarkan hasil perhitungan SPSS versi 20, diketahui bahwa variabel Y memiliki nilai tertinggi 95 dan nilai terendah 75, sehingga rentangnya (Range) 20 dan rata-rata (mean) nilainya 84,59, sementara standar deviasinya sebesar 5,500. Dengan nilai rata-rata sebesar 84,59, maka dapat dikatakan bahwa kualitas prestasi belajar siswa pada mata pelajaran Alquran Hadis di Kelas V MIN 10 Ciamis termasuk kategori sangat 
tinggi, karena jumlah rata-rata $($ mean $)=84,59: 15$ (jumlah butir angket $)=$ 5,63 . Nilai 5,63 ini termasuk pada kategori sangat tinggi karena berada pada interval 4,6 - 5,5.

Dari data di atas, hasil penelitian ini menunjukkan bahwa nilai Signifikansi 0,959>0,05 yang berarti ada pengaruh kinerja guru dalam pelaksanaan pembelajaran terhadap prestasi belajar siswa pada mata pelajaran Alquran-Hadis kelas V di MIN 10 Ciamis.

Penelitian ini membuktikan bahwa dalam kaitannya dengan proses belajar-mengajar, terdapat beberapa hal yang perlu diperhatikan. Pertama, prestasi belajar. Prestasi belajar adalah hasil usaha kegiatan belajar-mengajar yang dinyatakan dalam bentuk simbol, angka, huruf, maupun kalimat yang dapat mencerminkan hasil yang dicapai oleh setiap anak dalam periode tertentu (Surya, 1985, p. 71). Dalam Kamus Umum Bahasa Indonesia dijelaskan bahwa prestasi adalah hasil yang telah dicapai, dilakukan dan dikerjakan. Jadi segala sesuatu yang bersifat hasil berarti semuanya itu sudah dilaksanakan (Poerwadarminta, 2014, p. 910). Dengan demikian, prestasi merupakan perwujudan dan aktualisasi dari kemampuan dan belajar usaha siswa dalam waktu tertentu. Prestasi belajar sebagai kemampuan yang dimiliki siswa setelah siswa menerima pengalaman belajarnya. Dengan mengetahui prestasi belajar siswa, guru dapat menyatakan kedudukannya di dalam kelas apakah termasuk siswa yang pandai, sedang, atau kurang.

Parameter prestasi belajar mengacu pada kemampuan-kemampuan yang dimiliki siswa setelah siswa menerima pengalaman belajarnya dan menimba pengetahuan didalamnya, sehingga mendapatkan hasil sesuai dengan ketentuan yang berlaku. Guru mendapatkan kesimpulan tentang siswa di dalam kelas, apakah termasuk siswa ang pandai, sedang, atau kurang (Winkel, 2007, p. 58).

Kedua, hasil belajar. Hasil belajar merupakan suatu proses dipengaruhi oleh berbagai faktor yang secara garis besar dikelompokkan ke dalam dua bagian, yaitu faktor dari dalam diri siswa dan faktor luar siswa. Hasil belajar yang dicapai seseorang merupakan produk dari serangkaian interaksi komponen-komponen yang terlibat dalam proses belajar-mengajar. Jika dilihat dari segi individu, maka ada syarat yang harus dipenuhi agar menuju pada hasil yang baik. Kemauan adalah dorongan keinginan pada setiap manusia untuk membentuk dan merealisasikan diri. Artinya, siswa harus senantiasa mengembangkan segenap bakat dan kemampuannya, serta meningkatkan taraf kehidupan.

Ketiga, faktor fisiologis. Faktor fisiologis atau faktor kondisi fisik siswa merupakan faktor yang berpengaruh terhadap hasil belajar siswa. Faktor-faktor fisiologis ialah bagaimana kondisi fisiknya, panca indranya dan sebagainya. Termasuk di dalamnya antara lain kesehatan struktur dan fungsi-fungsi 
jasmani, serta hal yang berkaitan dengan kondisi fisiolgis lainnya. Sehubungan dengan hal itu, individu yang memiliki kondisi fisik yang baik dan berjuang untuk memperoleh hasil belajar yang baik dibandingkan dengan individu yang kondisi fisiknya kurang baik.

Keempat, faktor psikologis. Faktor Psikologis atau kematangan mental dan kemampuan intelektual sangat berpengaruh terhadap hasil belajar siswa. Dalam uraian Surya, kematangan mental yang telah dicapai merupakan faktor yang menentukan pencapaian hasil belajar seorang individu. Karena pada saat itulah organ mental telah berfungsi. Artinya, jika kematangan sudah tercapai, maka kemampuan mental sudah berfungsi secara baik termasuk untuk belajar (Surya M. , 2004, p. 64). Mengenai kemampuan intelektual siswa menurut Sudjana menjelaskan bahwa faktor kemampuan intelektual peserta didik besar sekali pengaruhnya terhadap hasil belajar yang dicapai, seperti yang dikemukakan oleh Clark, hasil belajar siswa di sekolah 70\% dipengaruhi oleh kemampuan intelektual siswa dalam 30\% dipengaruhi oleh lingkungan (Sudjana, 2002, p. 39).

Kelima, motivasi belajar. Motivasi belajar ialah keseluruhan daya penggerak dalam jiwa manusia untuk menimbulkan kegiatan belajarnya (Winkel, 2007, p. 27). Motivasi belajar ialah faktor psikis yang bersifat nonintelektual. Motivasi belajar memiliki peranan yang khas dalam belajar, yaitu dalam hal gairah dan semangat belajar. Belajar yang dilandasi dengan motivasi yang kuat mempunyai banyak energi untuk melakukan kegiatan belajar dan memiliki kecenderungan dapat meningkatkan hasil belajar.

Keenam, minat belajar. Minat belajar menentukan sukses atau gagalnya suatu kegiatan seseorang. Minat yang besar akan mendorong motivasi, demikian juga dalam kegiatan belajar. Minat mengandung arti kecenderungan yang menetap dalam diri individu untuk merasa senang atau tidak senang pada bidang atau hal tertentu. Minat juga turut berpengaruh terhadap hasil belajar, karena pelajaran yang baik pelajaran yang tidak diminati akan menimbulkan hilangnya motivasi untuk mempelajarinya.

Ketujuh, sikap peserta didik dalam kegiatan pembelajaran. Kegiatan peserta didik dalam proses belajar-mengajar tergantung kepada sikapnya. Seperti halnya juga minat, sikap memiliki ketergantungan kepada lingkungan sekitarnya. Berdasarkan beberapa penelitian terbukti bahwa kegiatan siswa dalam belajar seperti drop out, disebabkan karena sikap yang kurang baik dari siswa itu sendiri (Surya M. , 2004, p. 69).

Kedelapan, bakat siswa. Bakat siswa dapat mempunyai pengertian yang lebih dekat dengan pengertian kata attitude yang berarti kecakapan pembawaan, yaitu mengenai kesanggupan-kesanggupan (potensi-potensi) tertentu. Kesembilan, sifat-sifat pribadi siswa. Sifat-sifat pribadi siswa yang turut 
berpengaruh terhadap hasil belajar, yaitu kepribadian siswa masing-masing. Pribadi siswa yang satu berbeda dengan yang lain, ada yang keras hati, tekun, malas, dan halus perasaannya. Sifat-sifat pribadi yang ada pada diri seseorang itu sedikit banyak mempengaruhi hasil belajar siswa di sekolah.

Terlepas dari beberapa hal penting yang harus hadir dalam setiap proses kegiatan belajar-mengajar adalah, pertama, pendidik. Pendidik atau guru adalah tenaga profesional yang berfungsi sebagai mediator dalam belajar. Guru dapat pula dimaknai sebagai perantara dalam usaha memperoleh perubahan tingkah laku pada diri siswa melalui proses belajar mengajar.

Kedua, kurikulum. Kurikulum merupakan keseluruhan program pelajaran yang secara resmi untuk dilaksanakan oleh guru dan siswa. Kurikulum juga merupakan program pendidikan yang khusus terdapat di sekolah. Ketiga metode mengajar, yaitu cara yang dipergunakan guru dalam menyampaikan materi pelajaran kepada siswa di dalam kelas yang berpengaruh terhadap prestasi belajar siswa, karena metode yang kurang baik akan menyebabkan siswa rendah prestasi belajarnya.

Ketiga, waktu belajar. Faktor waktu belajar merupakan hal yang menentukan terlaksana atau tidaknya tujuan pembelajaran yang direncanakan. Berkaitan dengan proses belajar mengajar, faktor waktu belajar memang peranan penting karena tidak semua waktu baik untuk digunakan siswa dalam belajar. Dalam hal ini dapat dikemukakan waktu pagi akan lebih baik untuk belajar Dibandingkan dengan waktu tengah hari. Walaupun demikian, pada dasarnya semua waktu itu sama walaupun pada kondisi tertentu waktu mengakibatkan berhasil atau tidaknya suatu tujuan belajar.

Adapun pengertian pembelajaran Alquran-Hadis di Madrasah Ibtidaiyah merupakan sumber utama ajaran Islam. Dalam pengertian bahwa AlquranHadis merupakan sumber dari berbagai disiplin ilmu pengetahuan Islam, seperti akidah, akhlak, hingga fikih, sehingga kajiannya berada disetiap unsur tersebut. Mata pelajaran Alquran-Hadis di Madrasah Ibtidaiyah merupakan salah satu mata pelajaran PAI yang menekankan pada kemampuan membaca dan menulis Alquran-Hadis yang benar, serta hafalan terhadap surat-surat pendek dalam Alquran. Pengenalan arti atau makna secara sederhana dari surat-surat tersebut dan Hadis-Hadis tentang akhlak terpuji yang lekat dengan pengamalan dalam kehidupan sehari-hari.

Secara substansial, materi PAI ini sejalan dengan misi utama pendidikan, yaitu: (1) Pengembangan potensi dan kapasitas belajar peserta didik yang menyangkut rasa ingin tahu, percaya diri; (2) pengembangan baca-tulis-hitung dan bernalar, keterampilan hidup, dasar-dasar keimanan dan ketakwaan terhadap Allah Swt; (3) Fondasi bagi pendidikan berikutnya (Departemen Agama RI, 2013, p. 4). Dengan demikian, mata pelajaran Alquran-Hadis 
memiliki konstribusi dalam memberikan motivasi kepada peserta didik untuk mencintai kitab sucinya, mempelajari dan mempraktikan ajaran dan nilai-nilai yang terkandung dalam Alquran-Hadis yang menjadi sumber utama ajaran agama Islam dan sekaligus menjadi pegangan dan pedoman hidup dalam kehidupan sehari-hari (Departemen Agama RI, 2013, p. 5).

\section{Kesimpulan}

Kesimpulan mengenai pengaruh kinerja guru dalam pelaksanaan pembelajaran pada mata pelajaran Alquran-Hadis di MIN 10 Ciamis, maka dapat diambil beberapa kesimpulan, yaitu kinerja guru dalam pelaksanaan pembelajaran pada mata pelajaran Alquran Hadis Kelas V di MIN 10 Ciamis mencapai rata-rata 49,38 dan standar deviasi sebesar 3,850. Sementara interpretasi jawaban responden pada angket menunjukkan kualifikasi cukup. Prestasi belajar siswa pada mata pelajaran Alquran-Hadis, berdasarkan hasil penelitian, diperoleh rata-rata sebesar 84,59 dan standar deviasi 5,500. Hal ini menunjukkan kualifikasi sangat tinggi. Hasil penelitian ini menunjukkan bahwa nilai Signifikansi 0,959>0,05 yang berarti ada pengaruh kinerja guru dalam pelaksanaan pembelajaran terhadap prestasi belajar siswa pada mata pelajaran Alquran-Hadis kelas V di MIN 10 Ciamis.

\section{DAFTAR PUSTAKA}

Arikunto, S. (2000). Prosedur Penelitian: Suatu Pendekatan Praktik. Jakarta: Rineka Cipta.

Barizi, A. (2009). Menjadi Guru Unggul. Yogyakarta: Ar-Ruzz Media.

Departemen Agama RI. (2013). Pembelajaran Al-Qur'an-Hadits. Jakarta: Depag.

Majid, A. (2012). Perencanaan Pembelajaran. Bandung: PT Remaja Rosdakarya.

Nazir. (1988). Metode Penelitian. Jakarta: Ghalia Indonesia.

Poerwadarminta. (2014). Kamus Umum Bahasa Indonesia. Jakarta: PT Balai Pustaka.

Priyatno, D. (2008). Mandiri Belajar SPSS. Yogyakarta: Mediakom.

Ridwan. (2007). Belajar Mudah Penelitian untuk Guru, Karyawan dan Peneliti Pemula. Bandung: PT Remaja Rosdakarya.

Rusman. (2015). Pembelajaran Tematik Terpadu. Jakarta: PT Raja Grafindo Persada.

Somantri, A., \& Muhidin, S. A. (2006). Aplikasi Statistika dalam Penelitian. Bandung: Pustaka Setia. 
Sudjana, N. (1989). Dasar-Dasar Proses Belajar-Mengajar. Bandung: Sinar Baru.

Sudjana, N. (2002). Penilaian Hasil Proses Belajar-Mengajar. Bandung: Remaja Rosdakarya.

Sugiyono. (2009). Metode Penelitian Bisnis: Pendekatan Kualitatif, Kuantitatif dan ReD. Bandung: Alfabeta.

Sukardi. (2007). Metodologi Penelitian Pendidikan. Yogyakarta: Bumi Aksara.

Sulistyo, B. (2010). Metode Penelitian. Jakarta: Penaku.

Supardi. (2013). Kinerja Guru. Jakarta: PT Raja Grafindo Persada.

Surya, M. (1985). Psikologi Pendidikan. Bandung: PT Rineka Cipta.

Surya, M. (2004). Psikologi Pembelajaran dan Pengajaran. Bandung: Pustaka Bani Quraisy.

Veithzal, R. (2004). Manajemen Sumber Daya Manusia untuk Perusahaan: Dari Teori ke Praktik. Jakarta: PT Raja Grafindo Persada.

Winkel, W. S. (2007). Psikologi Pengajaran. Yogyakarta: Media Abadi. 
